\title{
Response of cattle with clinical osteochondrosis to mineral supplementation
}

\begin{tabular}{|c|c|}
\hline $\begin{array}{l}\text { Authors: } \\
\text { Gerjan van de } \\
\text { Geoffrey T. Fo } \\
\text { Frederick K. B } \\
\text { Heinz H. Meis } \\
\text { Lubbe Jacobs } \\
\text { Leon Prozesky }\end{array}$ & $\begin{array}{l}\text { r Veen }^{1} \\
\text { sgate }^{2} \\
\text { otha }^{1} \\
\text { sner }^{1}\end{array}$ \\
\hline $\begin{array}{l}\text { Affiliations: } \\
\text { 'Department } \\
\text { Sciences, Uni } \\
\text { Pretoria, Sout }\end{array}$ & $\begin{array}{l}\text { of Paraclinical } \\
\text { ersity of } \\
\text { h Africa }\end{array}$ \\
\hline $\begin{array}{l}\text { 2Department } \\
\text { Animal Studie } \\
\text { Pretoria, Sout }\end{array}$ & $\begin{array}{l}\text { ff Production } \\
\text { s, University of } \\
\text { h Africa }\end{array}$ \\
\hline $\begin{array}{l}{ }^{2} \text { Lubern Anim } \\
\text { Hartswater, Sc }\end{array}$ & $\begin{array}{l}\text { al Feeds, } \\
\text { puth Africa }\end{array}$ \\
\hline $\begin{array}{l}\text { Correspondin } \\
\text { Gerjan van de } \\
\text { gerjan@delta। }\end{array}$ & $\begin{array}{l}\text { g author: } \\
\text { r Veen, } \\
\text { mune.co.za }\end{array}$ \\
\hline $\begin{array}{l}\text { Dates: } \\
\text { Received: } 28 \text { s } \\
\text { Accepted: } 25 \\
\text { Published: } 24\end{array}$ & $\begin{array}{l}\text { Nept. } 2016 \\
\text { Nov. } 2016 \\
\text { Feb. } 2017\end{array}$ \\
\hline $\begin{array}{l}\text { How to cite th } \\
\text { Van der Veen, } \\
\text { G.T., Botha, F.I } \\
\text { H.H., Jacobs, L } \\
\text { 2017, 'Respon } \\
\text { with clinical o } \\
\text { to mineral sup } \\
\text { Onderstepoor } \\
\text { Veterinary Res } \\
\text { a1365. https:/ } \\
\text { org/10.4102/c }\end{array}$ & $\begin{array}{l}\text { is article: } \\
\text { G., Fosgate, } \\
\text {.., Meissner, } \\
\text {. \& Prozesky, L., } \\
\text { se of cattle } \\
\text { steochondrosis } \\
\text { plementation', } \\
\text { t Journal of } \\
\text { earch } 84(1) \text {, } \\
\text { /doi. } \\
\text { jur.v84i1.1365 }\end{array}$ \\
\hline $\begin{array}{l}\text { Copyright: } \\
\text { (c 2017. The A } \\
\text { Licensee: AOS } \\
\text { is licensed unc } \\
\text { Creative Comr } \\
\text { Attribution Lic }\end{array}$ & $\begin{array}{l}\text { uthors. } \\
\text { IS. This work } \\
\text { ler the } \\
\text { nons } \\
\text { ense. }\end{array}$ \\
\hline Read online: & \\
\hline 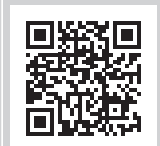 & $\begin{array}{l}\text { Scan this QR } \\
\text { code with your } \\
\text { smart phone or } \\
\text { mobile device } \\
\text { to read online. }\end{array}$ \\
\hline
\end{tabular}

Authors:

Gerjan van der Vee

Frederick K. Botha ${ }^{1}$

Heinz H. Meissner

Lubbe Jacobs ${ }^{3}$

on Prozesk

Sciences, University of

Pretoria, South Africa

${ }^{2}$ Department of Production Animal Studies, University of

${ }^{3}$ Lubern Animal Feeds,

Corresponding author:

Gerjan van der Veen,

Dates:

Received: 28 Sept. 2016

Accepted: 25 Nov. 2016

How to cite this article: Van der Veen, G., Fosgate, B., Botha, F.K, Meissner, 2017, 'Response of cattle with clinical osteochondrosis Onderstepoort Journal of Veterinary Research 84(1), a1365. https://doi.

Copyright:

(c) 2017. The Authors. Licensee: AOSIS. This work is licensed under the Creative Commons Attribution License.

mobile device
to read online.
Since 1982, farmers in the North West province and other parts of South Africa have noticed an increase in the incidence of lameness in cattle. Macro- and microscopical lesions of joints resembled osteochondrosis. Pre-trial data indicated that cattle with osteochondrotic lesions recovered almost completely when fed a supplement containing bio-available micro- and macrominerals of high quality. In the present trial, 43 clinically affected cattle of varying ages (1-5 years) and sexes were randomly divided into three groups. Each group was fed the same commercial supplement base with differing micro- and macromineral concentrations to determine the effect of mineral concentrations on the recovery from osteochondrosis. Both supplements 1 and 2 contained 25\% of the recommended National Research Council (NRC) mineral values. Additional phosphate was added to supplement 2. Supplement 3, containing $80 \%$ of the NRC mineral values, was used as the control. Results from all three groups indicated no recovery from osteochondrosis. Urine $\mathrm{pH}$ of a small sample of the test cattle showed aciduria $(\mathrm{pH}<6)$. Supplement analysis revealed addition of ammonium sulphate that contributed sulphate and nitrogen to the supplement. Supplementary dietary cation anion difference (DCAD) values were negative at $-411 \mathrm{mEq} / \mathrm{kg},-466 \mathrm{mEq} / \mathrm{kg}$ and $-467 \mathrm{mEq} / \mathrm{kg}$ for supplements 1, 2 and 3, respectively, whereas the pre-trial supplement was calculated at $+19.87 \mathrm{mEq} / \mathrm{kg}$. It was hypothesised that feeding a low (negative) DCAD diet will predispose growing cattle to the development of osteochondrosis or exacerbate subclinical or clinical osteochondrosis in cattle.

\section{Introduction}

'Osteochondrosis' is a broad term pertaining to a group of lesions associated with the persistence of growth cartilage in the epiphyseal or metaphyseal growth plate as a result of failure of endochondral ossification (Laverty \& Girard 2013; Olsson 1987; Olsson \& Reiland 1977; Ytrehus, Carlson \& Ekman 2007). König first introduced the term in 1888 to describe a pathological condition of the articular cartilage that leads to the formation of loose bodies in the joint (Ytrehus et al. 2007).

Different aetiological factors for osteochondrosis have been proposed. Rapid growth has been described as one of the main contributing factors predisposing to the development of osteochondrosis (Ekman \& Carlson 1998; Olsson \& Reiland 1977; Reiland 1977). Osteochondrosis has been described in pigs (Grøndalen 1974), dogs (Trostel, McLaughlin \& Pool 2002), newborn lambs (Corbellini et al. 1991), poultry (Whitehead 1997), turkeys (Poulos 1977), horses (Jeffcott 1991), cattle (Trostle et al. 1998), cats (Ralphs 2005) and rats (Kato \& Onodera 1984).

Since 1982, farmers in the North West province and other parts of South Africa have noticed an increase in the incidence of lameness in cattle. Clinical signs included varying degrees of lameness and peri-articular swelling, especially of the stifle joints. Macro- and microscopical lesions of joints resembled osteochondrosis. The initial aetiological factor thought to predispose to the development of osteochondrosis was that of a mineral deficiency, particularly phosphate. The North West province of South Africa is known for its mineral-related pathologic conditions such as osteomalacia, botulism (Theiler, Green \& Du Toit 1928) and Vryburg hepatosis (Elsenbroek \& Neser 2002; Neser et al. 1997). A survey conducted in 2004 indicated that several similar factors such as the breeding season, age, sex, anatomical conformation, nutritional supplementation and management were all commonly found throughout the affected geographical region. It was concluded that osteochondrosis is not the result of a single factor, but a multifactorial problem (Prozesky et al. 2016).

The most common joints of cattle affected by osteochondrosis are the shoulder, elbow and stifle joint (Hill, Sutton \& Thompson 1998; Jensen et al. 1981; Reiland et al. 1977; Trostle et al. 1997; 
Weisbrode et al. 1982). Peri-articular swelling as a result of inflammation (Trostle et al. 1998) can be noticed and is most evident in the elbow and stifle joints. Osteochondrosis of the stifle joint alters the anatomical conformation of the hind leg. The normal angular conformation is lost as the affected hind leg straightens as the lesion progresses in severity (Hill et al. 1998). Severely affected cattle adapt a sawhorse stance to reduce the load on affected joints.

Several immature Brahman cattle of both sexes (exact number unknown) suffering from varying degrees of lameness and peri-articular swelling (clinical osteochondrosis) were included in a feeding trial (henceforth referred to as the pretrial) during December 2012 at Onderstepoort. The purpose of the trial was to determine if cattle with clinical osteochondrosis would benefit from additional mineral supplementation. The supplement was fed for a period of 3 weeks and contained above normal levels of bio-available micro- and macrominerals. The clinically affected cattle responded positively with a marked decrease in the severity of lameness and size of the peri-articular swelling (unpublished data). Results of the pre-trial emphasised the importance of determining the concentration of minerals necessary to be included in a supplement that would benefit cattle suffering from clinical osteochondrosis. This study was conducted to investigate the required mineral levels that would promote clinical improvement of cattle with clinical osteochondrosis.

\section{Material and methods}

Forty-three clinically affected Brahman cattle of varying ages and sexes, originating from the same geographical area, were included in the feeding trial. Animals were weighed and clinically evaluated at the start of the trial.

The trial supplements were formulated to have the same basic ingredients and to only vary in micro- and macromineral concentrations. The three supplements were as follows:

- Supplement 1 contained $25 \%$ of the recommended NRC (2001) mineral values. No additional phosphate was added to the supplement.

- Supplement 2 contained $25 \%$ of the recommended NRC (2001) mineral values with the exception of added monoammonium phosphate (MAP) to an equivalent level to that of supplement 3.

- Supplement 3 contained $80 \%$ of the recommended NRC (2001) mineral levels and was used as the control diet.

For each supplement, the same mineral premix base, Arthrocure B ( $\mathrm{ANH}^{\circledR}$, pers. comm., 2013), was included to ensure comparable standard and quality of minerals. The bioavailability of both micro- and macrominerals included in the Arthrocure premix is high (composition not shown because of confidentiality implications). The absorption percentage of the phosphate source used (MAP) in supplements 2 and 3 according to the National Research
Council (2001) is $80 \%$. Ingredients and amounts used to formulate the trial supplementary feeds are provided in Table 1.

Cattle had ad lib access to baled Eragrostis teff hay for the total duration of the trial. Supplementary feed was collected and weighed on a weekly basis to determine the average individual consumption (grams) per day. The cattle were fed for a total period of 12 weeks.

The cattle were evaluated clinically every second week for the total duration of the trial. Three independent observers each individually recorded clinical signs to limit any biased decisions. Visual evaluation included grading of both the size of the peri-articular swelling and the degree of lameness. Acute peri-articular swelling has a pronounced bulging appearance, whereas chronic peri-articular swelling has a more flattened appearance because of thickening of the joint capsule that depresses the swelling. The chronicity, size and location of each peri-articular swelling were recorded in a format similar to Figure 1.

Lameness was graded on a scale of severity as shown in Table 2.

\section{Statistical analysis}

An overall disability score was calculated as the sum of the scores for each clinical category (lameness, acute and fibrosis) over both hind legs (left and right). The change in each clinical category score was calculated by subtracting off the baseline from all subsequent values (forming 'delta' scores). Delta scores were assessed for normality by calculating descriptive statistics, plotting histograms and performing the Anderson-Darling test in available software (MINITAB Statistical Software, Release 13.32, Minitab Inc, State College, PA, USA). Categorical data were described using proportions and $95 \%$ mid-P exact confidence intervals (CI) and compared among diets using chi-square tests.

TABLE 1: List of ingredients and amounts used to formulate the respective trial supplements.

\begin{tabular}{|c|c|c|c|c|c|c|}
\hline \multirow[t]{2}{*}{ Ingredients } & \multicolumn{2}{|c|}{$\begin{array}{c}\text { Supplementary } \\
\text { feed } 1\end{array}$} & \multicolumn{2}{|c|}{$\begin{array}{l}\text { Supplementary } \\
\text { feed } 2\end{array}$} & \multicolumn{2}{|c|}{$\begin{array}{c}\text { Supplementary } \\
\text { feed } 3\end{array}$} \\
\hline & As is $\%$ & $\operatorname{Mix}(\mathrm{kg})$ & As is $\%$ & $\operatorname{Mix}(\mathrm{kg})$ & As is $\%$ & Mix (kg) \\
\hline Salt & 25.00 & 250 & 25.0 & 250 & 25.00 & 250.0 \\
\hline Bran 15\% & 15.00 & 150 & 12.5 & 125 & 12.50 & 125.0 \\
\hline Hominy chop & 13.00 & 130 & 12.4 & 124 & 12.40 & 124.0 \\
\hline Peanut shells & 12.70 & 127 & 7.8 & 78 & 7.00 & 70.0 \\
\hline Urea & 12.00 & 120 & 11.0 & 110 & 11.00 & 110.0 \\
\hline Molasses & 12.00 & 120 & 12.0 & 120 & 11.95 & 119.5 \\
\hline Sunflower O/C 38\% & 6.00 & 60 & 6.0 & 60 & 6.00 & 60.0 \\
\hline Ammonium sulphate & 3.00 & 30 & 3.0 & 30 & 3.00 & 30.0 \\
\hline Limestone & 1.00 & 10 & 5.0 & 50 & 5.00 & 50.0 \\
\hline $\begin{array}{l}\text { Mono-ammonium } \\
\text { phosphate (MAP) }\end{array}$ & 0.00 & 0 & 5.0 & 50 & 5.00 & 50.0 \\
\hline DSM Arthrocure B & 0.30 & 3 & 0.3 & 3 & 1.15 & 11.5 \\
\hline Total & 100 & 1000 & 100 & 1000 & 100 & 1000 \\
\hline
\end{tabular}

This table presents the formulation of the three different supplementary feeds used during the trial. The original supplement formulation did not include ammonium sulphate, and it was only after analysis that the inclusion thereof became known. Both the as is \% and kilogram $(\mathrm{kg})$ amounts of the respective ingredients for each supplement are presented. 
Lesion scoring 2013: Onderstepoort study 2013

\begin{tabular}{|c|c|c|c|c|c|c|c|c|c|c|c|c|c|c|c|c|c|c|c|c|c|c|c|c|c|c|}
\hline Date: & \multicolumn{8}{|c|}{$\begin{array}{l}\text { Acute peri-articular } \\
\text { swelling }\end{array}$} & \multicolumn{8}{|c|}{$\begin{array}{l}\text { Chronic peri-articular swelling } \\
\text { (fibrosis of joint capsule) }\end{array}$} & \multicolumn{10}{|c|}{ Degree of lameness } \\
\hline Evaluator: & \multicolumn{2}{|c|}{$S$} & \multicolumn{2}{|c|}{ M } & \multicolumn{2}{|c|}{ L } & \multicolumn{2}{|c|}{$X L$} & \multicolumn{2}{|c|}{ S } & \multicolumn{2}{|c|}{ M } & \multicolumn{2}{|c|}{ L } & \multicolumn{2}{|c|}{$X L$} & \multicolumn{2}{|c|}{0} & \multicolumn{2}{|c|}{1} & \multicolumn{2}{|c|}{2} & \multicolumn{2}{|c|}{3} & \multicolumn{2}{|c|}{4} \\
\hline $\begin{array}{l}\text { Animal } \\
\text { number: }\end{array}$ & L & $\mathrm{R}$ & L & $\mathrm{R}$ & L & $\mathrm{R}$ & L & $\mathrm{R}$ & L & $\mathrm{R}$ & L & $\mathrm{R}$ & L & $\mathrm{R}$ & L & $\mathrm{R}$ & L & $\mathrm{R}$ & L & $\mathrm{R}$ & L & $\mathrm{R}$ & $\mathrm{L}$ & $\mathrm{R}$ & L & $\mathrm{R}$ \\
\hline
\end{tabular}

The figure presents the lesion score evaluation form used to record the size of the peri-articular swelling of the stifle joint and the severity of lameness of each animal included in the trial. Cattle were evaluated every second week for the total duration of the trial. S, small peri-articular swelling of the stifle joint (approx. diameter $2.5 \mathrm{~cm}$ ); $\mathrm{M}$, medium peri-articular swelling of the stifle joint (approx. diameter $6 \mathrm{~cm}$ ); L, large peri-articular swelling of the stifle joint (approx. diameter $10 \mathrm{~cm}$ ); XL, extra-large peri-articular swelling of the stifle joint (approx. diameter $>10 \mathrm{~cm}$ ); L, left stifle joint; $R$, right stifle joint.

FIGURE 1: Visual lesion evaluation form.

TABLE 2: Grading score for lameness.

\begin{tabular}{ll}
\hline Lameness score & Score definition \\
\hline 0 & No clinical signs of lameness observed \\
1 & Conformational changes noticed and slight lameness observed \\
2 & Moderate lameness observed \\
3 & Severely affected but still weight-bearing \\
4 & Severely affected with very little to non-weight-bearing \\
\hline
\end{tabular}

This table presents the criteria used to determine the severity of lameness. Each hind leg of the animal was scored individually.

Categorical data analysis was performed using available freeware (Epi Info, version 6.04, CDC, Atlanta, GA, USA). Delta scores were descriptively presented as medians and ranges and transformed by ranking prior to statistical analysis. Delta scores were compared among diet groups using linear mixed models that included animal as a random effect and diet as a fixed effect. Unless stated otherwise, statistical analyses were performed using commercially available software (IBM SPSS Statistics Version 22, International Business Machines Corp., Armonk, NY, USA) and results interpreted at the 5\% level of significance.

Forty-three cattle with clinical osteochondrosis were randomly divided into three groups. Groups were housed in separate camps, and each camp was equipped with a water trough (municipal water), hayrack and two Taltec feed troughs that provided sufficient feeding space.

\section{Clinical examination and urinalysis}

The clinical examination was done to investigate any possible causes for the negative results obtained during the trial. Results obtained from the clinical examination were used for differential diagnoses only. Cattle sample size was not statistically calculated as the examination was only done after the negative results were obtained and was for interest' sake only.

Urine was collected from cattle that urinated voluntarily in the crush. The same animals from which urine was collected were clinically examined. Observers used a pole with a cup attached at the end to collect the free flow urine sample. Collected urine was analysed immediately with the Combur $^{9}$ Test $^{\circledR}$ (Roche) urine dipstick.

\section{Results}

\section{Initial weight, supplement and phosphate intake}

Statistical analysis indicated that there was no significant difference between the starting weights of the respective groups. The average weight of groups 1, 2 and 3 was $310 \mathrm{~kg}$, $290 \mathrm{~kg}$ and $267 \mathrm{~kg}$, respectively. Supplement intake varied between the groups, with the average collective daily supplement intakes for groups 1, 2 and 3 being $370 \mathrm{~g}$, $255 \mathrm{~g}$ and 292 g, respectively. Daily supplement intake calculated as grams consumed per $\mathrm{kg}$ live weight was $1.19 \mathrm{~g}, 0.88 \mathrm{~g}$ and $0.91 \mathrm{~g}$ per kg live weight, respectively, for groups 1, 2 and 3.

The calculated average daily phosphate intake per animal differed between the groups. Consumed values are presented in Table 3.

\section{Lameness evaluation}

The size of the peri-articular swelling and the degree of lameness of the trial cattle were used to determine the effect of the supplements. Visual grading of lesions has been statistically proven to be a valid method (unpublished data: K. Botha, 2016). Analysis of the initial values for all the cattle indicated that there were no significant differences pertaining to the sex, age, weight, lameness score, acute peri-articular swelling score, chronic peri-articular swelling (fibrosis) score and the overall disability score. The majority of cattle included in group 1 had acute peri-articular swellings, whereas the cattle included in groups 2 and 3 had very similar numbers of acute peri-articular swelling and chronic peri-articular swelling scores. Although the degree of lameness varied between animals within a group, the average lameness score ranged between 1 and 2 for all three groups.

Study results indicated no significant difference between the degree of lameness, acute peri-articular swelling, chronic peri-articular swelling and total disability score between the respective groups.

\section{Clinical examination and urinalysis}

Four cattle from which urine could be collected were used for the clinical examination. None of the clinical parameters 
TABLE 3: Calculated average daily phosphate intake of respective sub-groups.

\begin{tabular}{lcccc}
\hline $\begin{array}{l}\text { Supplement and } \\
\text { sub-group }\end{array}$ & $\begin{array}{c}\text { Average starting weight of } \\
\text { the cattle (kg) }\end{array}$ & $\begin{array}{c}\text { Average supplement } \\
\text { consumption (g/day/animal) }\end{array}$ & $\begin{array}{c}\text { Supplement P measured } \\
\text { value (\%DM) }\end{array}$ & $\begin{array}{c}\text { Average phosphate intake } \\
\text { (g/day/animal) } \dagger\end{array}$ \\
\hline Supplement 1 & 310 & 370 & 0.94 & $\begin{array}{c}\text { \% P consumed less than } \\
\text { cattle fed supplement 3 }\end{array}$ \\
Supplement 2 & 290 & 255 & 1.59 & -47.7 \\
Supplement 3 & 267 & 292 & 1.79 & 4.05 \\
\hline
\end{tabular}

$\dagger$, Calculated respective phosphate intake (grams per animal per day) to indicate the difference of phosphate intake between the respective groups.

were abnormal for any of the four cattle examined. The urine of the respective animals was chemically evaluated with a urine test strip (Combur ${ }^{9}$ Test $^{\circledR}$; Roche) and indicated a urinary $\mathrm{pH}$ of $<6$ for all the four cattle.

\section{Statistical analysis}

Statistical analysis indicated no significant difference between the respective supplements with regard to the measured parameters, with the exception of the acute peri-articular score of group 1 (Table 4). The significance thereof is, however, not of importance as the cattle only developed the more chronic form of the osteochondrotic peri-articular swelling (chronic peri-articular swelling).

\section{Discussion}

The trial was conducted to determine the level of micro- and macrominerals required to be included in a supplement that would improve the clinical condition of cattle clinically affected by osteochondrosis.

The three supplements contained the same basic ingredients and only varied in mineral concentrations. The mineral levels of supplement 3 were based on those of the 2012 pre-trial supplement that had a significant positive effect when fed to cattle with clinical osteochondrosis (Prozesky et al. 2016).

The daily average supplement intake per animal between the groups varied (Table 3 ). Differing average starting weights (Table 3) and ad lib access to high quality Eragrostis teff hay would both have influenced the average daily consumption of supplements. Eragrostis teff hay is highly palatable and nutritious roughage that would contribute a large proportion of the nutritional daily requirements of the cattle. The most important factor was to calculate the mineral intake especially that of phosphate as it was thought that higher phosphate intake played a key role in the recovery and prevention of osteochondrotic lesions. Calculated average daily phosphate intake per animal differed among the respective groups. Group 3 had an average phosphate intake of $5.14 \mathrm{~g}$ per animal per day. Cattle of groups 1 and 2 consumed $47.7 \%$ (3.47 g) and 16\% (4.05 g) less phosphate on a daily basis, respectively, when compared to the phosphate intake of group 3. It was expected that especially the cattle of group 3 would have responded positively to the higher micro- and macromineral intake, with group 1 responding the least to the supplementation.

Peri-articular swelling and lameness can occur simultaneously or independently of each other (Trostle et al. 1997, 1998). The size of the peri-articular swelling does not correlate with the
TABLE 4: Statistical analysis of the baseline values as well as study results.

\begin{tabular}{lcccccc}
\hline Parameters & \multicolumn{2}{c}{ Baseline values $(\boldsymbol{P}) \dagger$} & & \multicolumn{2}{c}{ Results $(\boldsymbol{P})$ \$ } \\
\cline { 2 - 3 } \cline { 6 - 6 } & Study 1 & Study 2 & & Study 1 & Study 2 \\
\hline Sex & 0.774 & 0.384 & & - & - \\
Age & 0.725 & 0.742 & & - & - \\
Weight & 0.454 & 0.452 & & - & - \\
Lameness score & 0.567 & 0.976 & & 0.122 & 0.084 \\
Acute peri-articular swelling & 0.111 & 0.343 & & $0.034 \S$ & 0.247 \\
Chronic peri-articular swelling & 1.000 & 0.141 & & 0.189 & 0.331 \\
Overall disability & 0.328 & 0.730 & & 0.093 & 0.261 \\
\hline
\end{tabular}

Significance based on a $95 \%$ confidence interval.

$\dagger$, Based on chi-square tests for categorical variables and Kruskal-Wallis tests for quantitative data; $\$$, comparison among diets based on mixed-effects linear model analysing the change in variables from baseline (after rank transformation of scores) and adjusting for repeated in variables from baseline (after rank transformation of scores) and adjusting for
measures by the addition of a random effect for animal; $\S$, indicates significance.

extent of the osteo-arthritic lesion (unpublished data from radiographic analysis: Van der Veen), but is merely an indication of excessive synovial fluid produced as a result of joint inflammation (Trostle et al. 1998).

No work to date has been conducted to determine the time period it takes for the joint to deposit additional connective tissue in the capsule.

Baseline data and the final study results for groups 1, 2 and 3 indicated no significant difference between the lameness, acute peri-articular swelling, chronic peri-articular swelling and total disability scores.

All the cattle included in the study had clinical osteochondrotic lesions with the affected period of each animal unknown to the investigators. Several animals with acute peri-articular swellings developed chronic peri-articular swellings during the course of the study. The shift in chronicity of the periarticular swelling is an indication that those animals did not respond to the supplementation but instead the severity of the osteochondrotic lesions remained the same or progressed.

It was expected that the cattle of this study fed supplement 3 would have responded positively in a similar fashion as did the cattle in the 2012 pre-trial, as the mineral levels included in supplement 3 resembled those of the pre-trial 2012 supplement.

The fact that none of the study cattle responded positively to any of the supplementations, regardless of different microand macromineral level intake between sub-groups, warranted further investigation. The results obtained in this study are contradictory to those observed during the 2012 pre-trial where cattle fed a supplement containing high levels of both micro- and macrominerals responded positively with a marked decrease in the severity of lameness and size of the peri-articular swelling (Prozesky et al. 2016). 
Possible factors that could lead to the development of aciduria were investigated. It is known from studies in dairy cows that a dietary cation anion difference (DCAD) value of $<-200 \mathrm{mEq} / \mathrm{kg}$ is effective in inducing a metabolic acidosis and aciduria (average pH 7) (DeGaris \& Lean 2008).

The DCAD value for the respective trial supplements as well as the 2012 pre-trial supplement was calculated by subtracting the anion value from the cation value.

The most common equation used is $\left[\left(\mathrm{Na}^{+}+\mathrm{K}^{+}\right)-\left(\mathrm{Cl}^{-}+\mathrm{S}^{2-}\right)\right]$ (DeGaris \& Lean 2008). There was a significant difference between the DCAD value of supplements 1,2 and 3 compared to that of the 2012 pre-trial supplement. Calculated DCAD values are provided in Table 5.

Further investigation into the composition of the trial supplements revealed that all three supplements contained the anionic salt, ammonium sulphate, whereas the pre-trial supplement did not contain an anionic salt, leading to a higher DCAD value.

A possible explanation why the elevated mineral intakes from supplements 2 and 3 did not result in recovery from osteochondrosis is as follows.

The plasma $\mathrm{pH}$ is regulated by four factors of which the strong ion difference is one. Intestinal absorption concentration of strong anions (chloride and sulphate) is more than that of strong cations (calcium, magnesium and ammonium) when salts like ammonium sulphate $\left[\left(\mathrm{NH}_{4}\right)_{2} \mathrm{SO}_{4}\right]$ are fed. The increased anion level in the plasma, in this case $\mathrm{SO}_{4}{ }^{2-}$, reduces the strong ion difference, inducing a strong ion metabolic acidosis (DeGaris \& Lean 2008). Metabolic acidosis increases the responsiveness of tissue receptors to parathyroid hormone (PTH) (Horst et al. 1997). Bone responds to PTH by the activation of osteocytes as well as the osteoclasts (La Perle \& Capen 2006) with osteoclastic activity increasing proportionally as the plasma becomes more acidic (Arnett 2003). Calcium can be mobilised from bone either in conjunction with or independently of PTH (DeGaris \& Lean 2008). Bone acts as a buffer during acute metabolic acidosis by binding hydrogen ions to carbonate and releasing the cation salts $\left(\mathrm{Na}^{+}, \mathrm{K}^{+}, \mathrm{Ca}^{2+}\right)$ associated with the carbonate into the extracellular fluid (Engelking 2011; Horst et al. 1997). This process, as well as the activation of osteoclasts through $\mathrm{PTH}$, functions as a buffer during chronic metabolic acidosis (Green \& Kleeman 1991).

TABLE 5: Calculated dietary cation anion difference values of respective supplements.

\begin{tabular}{lc}
\hline Supplement & Calculated DCAD value $(\mathrm{mEq} / \mathrm{kg}) \dagger$ \\
\hline Supplement 1 (Group1) & -411 \\
Supplement 2 (Group 2) & -466 \\
Supplement 3 (Group 3) & -467 \\
2012 pre-trial supplement & +19.87 \\
\hline
\end{tabular}

DCAD, dietary cation anion difference.

$\dagger$, DCAD value calculated with the following equation: $\left[\left(\mathrm{Na}^{+}+\mathrm{K}^{+}\right)-\left(\mathrm{Cl}^{-}+\mathrm{S}^{2-}\right)\right]$.
Renal function responds to PTH through reduced reabsorption of phosphate (phosphaturia) and increased reabsorption of calcium (La Perle \& Capen 2006) from the glomerular filtrate. Calcium is still excreted at elevated levels during metabolic acidosis despite the increased reabsorption action of PTH. The charge equivalence of albumin is altered during metabolic acidosis, which leads to the release of plasma protein bound calcium (up to $40 \%$ of the total calcium) increasing the amount filtered through the glomerulus of the kidney and ultimately excreted leading to increased mineral loss (Engelking 2011). The excess dietary anions in the plasma are filtered and excreted through the kidneys. The urine produced is acidic (aciduria) in nature because of the increased concentration of excreted anions (Spanghero 2004). A urinary $\mathrm{pH}<5.5$ indicates severe metabolic acidosis and should be avoided at all cost (Horst et al. 1997).

The majority of minerals reabsorbed from the skeleton of rats with metabolic acidosis occurred from the epiphysis, resulting in lower total bone volume of the metaphysis (Kraut et al. 1986). Mongin and Sauveur (1977) (q. Whitehead 1997) proposed that the anionic balance of a diet influenced the incidence rate of tibial dyschondroplasia (osteochondrosis) in chickens. Several studies followed that confirmed the proposal made by Mongin and Sauveur that metabolic acidosis increased the incidence of tibial dyschondroplasia in chickens (Whitehead 1997).

A new hypothesis was formulated based on the observations made during the trial. We hypothesise that chronic mild metabolic acidosis weakens the developing calcareous bone, consequently exposing particularly fast growing cattle to traumatic fracture of the subchondral bone and articular cartilage, leading to the development of lesions associated with osteochondrosis. This hypothesis also suggests that chronic metabolic acidosis will exacerbate subclinical or clinical osteochondrosis. These hypotheses require further investigation. It is important to consider not only the direct dietary cause of metabolic acidosis but to have a holistic approach which includes signalment, husbandry and regular analysis of both feed and water sources.

\section{Conclusion}

Investigation of cattle clinically affected by osteochondrosis in the North West province on a herd basis revealed that bulls were more prone and severely affected than cows, with young animals more frequently affected than adult animals (Prozesky et al. 2016). The higher frequency among young animals is in accordance with the definition, as 'osteochondrosis' is a term that pertains to a group of lesions associated with the persistence of growth cartilage in the epiphyseal or physeal growth plates as a result of failure of endochondral ossification.

Prozesky et al. (2016) as well as data from the pre-trial (not shown) indicated that cattle clinically suffering from osteochondrosis responded positively when fed a supplement containing high levels of bio-available micro- and macrominerals. 
The results from this study indicated that cattle with clinical osteochondrosis do not respond positively to a supplement with a low DCAD value, regardless of its micro- and macromineral concentration. The new hypothesis suggests that cattle supplemented for an extended period of time with a low DCAD feed are predisposed to the development of osteochondrosis or exacerbation of subclinical or clinical osteochondrosis. This hypothesis needs to be further investigated.

\section{Acknowledgements}

The authors thank Drs. Wilco Botha, André van den Berg, Benton van den Berg and Patrick Ntsibande for assisting with the data collection.

\section{Competing interests}

The authors declare that they have no financial or personal relationships that may have inappropriately influenced them in writing this article.

\section{Authors' contributions}

G.v.d.V. was the principal investigator, responsible for the experimental and project design, care of the experimental animals, data collection and interpretation thereof. G.T.F. was responsible for the statistical analysis. F.K.B. formulated the supplements and calculated the DCAD values. H.H.M. was the nutritional advisor and co-supervisor. L.J. did the mixing of the supplements. L.P. was the study supervisor.

\section{References}

Arnett, T., 2003, 'Regulation of bone cell function by acid-base balance', Proceeding of the Nutrition Society 62(2), 511-520. https://doi.org/10.1079/PNS2003268

Corbellini, C.N., Krook, L., Nathanielsz, P.W. \& Kallfelz, F.A., 1991, 'Osteochondrosis in fetuses of ewes overfed calcium', Calcified Tissue International 48(1), 37-45. https://doi.org/10.1007/BF02555794

DeGaris, P.J. \& Lean, I.J., 2008, 'Milk fever in dairy cows: A review of pathophysiology and control principles', The Veterinary Journal 176(1), 58-69. https://doi. org/10.1016/j.tvjl.2007.12.029

Ekman, S. \& Carlson, C.S., 1998, 'The pathophysiology of osteochondrosis', Veterinary Clinics of North America: Small Animal Practice 28(1), 17-32. https://doi. org/10.1016/S0195-5616(98)50002-2

Elsenbroek, J.H. \& Neser, J.A., 2002, 'An environmental application of regional geochemical mapping in understanding enzootic geophagia of calves in the Reivilo Area, South Africa', Environmental Geochemistry and Health 24(2), 159-181. https://doi.org/10.1023/A:1014247108504

Engelking, L., 2011, Textbook of veterinary physiological chemistry, 2nd rev. edn., pp. 489-495, Elsevier, Oxford.

Green, J. \& Kleeman, C.R., 1991, 'Role of bone in regulation of systemic acid-base balance', Kidney International 39(1), 9-26. https://doi.org/10.1038/ki.1991.2

Grøndalen, T., 1974, 'Osteochondrosis and arthrosis in pigs. I. Incidence in animals up to $120 \mathrm{~kg}$ live weight', Acta Veterinaria Scandinavica 15(1), 1-25.

Hill, B., Sutton, R. \& Thompson, H., 1998, 'Investigation of osteochondrosis in grazing beef cattle', Australian Veterinary Journal 76(3), 171-175. https://doi. org/10.1111/j.1751-0813.1998.tb10122.x
Horst, R.L., Goff, J.P., Reinhardt, T.A. \& Buxton, D.R., 1997, 'Strategies for preventing milk fever in dairy cattle 1, 2', Journal of Dairy Science 80(7), 1269-1280. https:// doi.org/10.3168/jds.S0022-0302(97)76056-9

Jeffcott, L.B., 1991, 'Osteochondrosis in the Horse-Searching for the key to pathogenesis', Equine Veterinary Journal 23(5), 331-338. https://doi.org/10. 1111/j.2042-3306.1991.tb03733.x

Jensen, R., Park, R.D., Lauerman, L.H., Braddy, P.M., Horton, D.P., Flack, D.E. et al., 1981, 'Osteochondrosis in feedlot cattle', Veterinary Pathology Online 18(4), 529-535.

Kato, M. \& Onodera, T., 1984, 'Spontaneous osteochondrosis in rats', Laboratory Animals 18(2), 179-187. https://doi.org/10.1258/002367784780891361

Kraut, J.A., Mishler, D.R., Singer, F.R. \& Goodman, W.G., 1986, 'The effects of metabolic acidosis on bone formation and bone resorption in the rat', Kidney International 30(5), 694-700. https://doi.org/10.1038/ki.1986.242

La Perle, K.M.D. \& Capen, C.C, 2006, 'Endocrine system', in M.D. McGavin \& J.F. Zachary (eds.), Pathologic basis of veterinary disease, 4th edn., pp. 693-742, Mosby Elsevier, St Louis, MO.

Laverty, S. \& Girard, C., 2013, 'Pathogenesis of epiphyseal osteochondrosis', The Veterinary Journal 197(1), 3-12. https://doi.org/10.1016/j.tvjl.2013.03.035

Mongin, P. \& Sauveur, B., 1977, 'Interrelationships between mineral nutrition, acidbase balance, growth and cartilage abnormalities', in Growth and poultry meat production, pp. 235-237, British Poultry Science, Edinburgh.

National Research Council, 2001, Nutrient requirements of dairy cattle, 7th rev. edn., National Academy of Sciences, Washington, DC.

Neser, J.A., De Vries, M.A., De Vries, M., Van der Merwe, A.J., Loock, A.H., Smith, H.J.C. et al., 1997, 'The possible role of manganese poisoning in enzootic geophagia and hepatitis of calves and lambs: To the editor', Journal of the South African Veterinary Association 68(1), 4-6. https://doi.org/10.4102/jsava.v68i1.856

Olsson, S.E. \& Reiland, S., 1977, 'The nature of osteochondrosis in animals. Summary and conclusions with comparative aspects on osteochondritis dissecans in Man' Acta radiologica. Supplementum 358, 299-306.

Olsson, S.E., 1987, 'General and aetiologic factors in canine osteochondrosis', Veterinary Quarterly 9(3), 268-278. https://doi.org/10.1080/01652176.1987.969 4112

Poulos, P.W., Jr., 1977, 'Tibial dyschondroplasia (osteochondrosis) in the Turkey. A morphologic investigation', Acta radiologica. Supplementum 358, 197-227.

Prozesky, L., Neser, J., Meissner, H., Botha, K., Jacobs, L., Shepstone, C. et al., 2016 'Preliminary report on osteochondrosis in cattle in the North-Western Parts of South Africa', Onderstepoort Journal of Veterinary Research 83(1), a1083. https:// doi.org/10.4102/ojvr.v83i1.1083

Ralphs, S.C., 2005, 'Bilateral stifle osteochondritis dissecans in a cat', Journal of the American Animal Hospital Association 41(1), 78-80. https://doi.org/10.5326/ 0410078

Reiland, S., 1977, 'The effect of decreased growth rate on frequency and severity of osteochondrosis in pigs', Acta radiologica. Supplementum 358, 107-122.

Reiland, S., Strömberg, B., Olsson, S.E., Dreimanis, I. \& Olsson, I.G., 1977 'Osteochondrosis in growing bulls. Pathology, frequency and severity on different feedings', Acta radiologica. Supplementum 358, 179-196.

Spanghero, M., 2004, 'Prediction of urinary and blood pH in non-lactating dairy cows fed anionic diets', Animal Feed Science and Technology 116(1), 83-92. https://doi. org/10.5326/0410078

Theiler, A., Green, H.H. \& Du Toit, P.J., 1928, 'Studies in mineral metabolism. III. Breeding of cattle on phosphorus deficient pasture', The Journal of Agricultural Science 18(3), 369-371. https://doi.org/10.1017/S0021859600019365

Trostel, C.T., McLaughlin, R.M. \& Pool, R.R., 2002, 'Canine lameness caused by developmental orthopedic diseases: Osteochondrosis', Compendium on Continuing Education for the Practicing Veterinarian-North American Edition 24(11), 836-857.

Trostle, S.S., Nicoll, R.G., Forrest, L.J. \& Markel, M.D., 1997, 'Clinical and radiographic findings, treatment, and outcome in cattle with osteochondrosis: 29 Cases (1986-1996)', Journal of the American Veterinary Medical Association 211(12), 1566-1570.

Trostle, S.S., Nicoll, R.G., Forrest, L.J., Markel, M. \& Nordlund, K., 1998, 'Bovine osteochondrosis', The Compendium on Continuing Education for the Practicing Veterinarian 20(7), 856-863.

Weisbrode, S.E., Monke, D.R., Dodaro, S.T. \& Hull, B.L., 1982, 'Osteochondrosis, degenerative joint disease, and vertebral osteophytosis in middle-aged bulls', Journal of the American Veterinary Medical Association 181(7), 700-705.

Whitehead, C.C., 1997, 'Dyschondroplasia in poultry', Proceedings of the Nutrition Society 56(3), 957-966. https://doi.org/10.1079/PNS19970101

Ytrehus, B., Carlson, C.S. \& Ekman, S., 2007, 'Etiology and pathogenesis of osteochondrosis', Veterinary Pathology 44(4), 429-448. https://doi.org/10.1354/ vp.44-4-429 